\title{
Vitamin D Status and Hypocalcemic Response to Protamine in Exercised and Non-exercised Dairy Cows
}

\author{
By J.Luthman and C. Korpe \\ Department of Cattle and Sheep Diseases, Swedish University of Agricultural Sciences, Uppsala, Sweden
}

\begin{abstract}
Luthman, J. and C. Korpe: Vitamin D status and the hypocalcemic response to protamine in exercised and non-exercised dairy cows. Acta vet. scand.: 1993, 34, 53-57. - Bone resorption was studied in post parturient cows using intravenous injection of protamine. Protamine inhibits bone resorption and the protamine-induced hypocalcemia can be taken as a measure of this process. The studies were performed in a herd where half of the cows had been tied indoors for $21 / 2$ years, the other half had been given daily exercise during the same period. All animals were fed in the same way.

The hypocalcemic response to protamine was the same in both groups, which indicates that exercise did not change bone resorption.

The serum levels of calcium, inorganic phosphorus and magnesium around parturition did not differ. The daily exposure to daylight increased the serum level of $25-(\mathrm{OH})$-cholecalciferol in late summer in the exercised group.
\end{abstract}

calcium.

\section{Introduction}

Parturient paresis continues to be a problem in high producing dairy cows. The knowledge about the causes to this disturbance in calcium homeostasis has during the years been summarized by several authors e.g. Braithwaite (1976) and Allen \& Sansom (1985). The onset of lactation heavily increases the demand for calcium, as a consequence the serum level declines in a varying degree. The cow's inability to rapidly meet the increased demand by increasing intestinal calcium absorption and the resorption from bone is generally considered as the crucial points.

There are several reports demonstrating a reduced bone resorption rate at the time around partus. Ramberg et al. (1970) reported from a kinetic study that the rate of calcium removal from bone was low immediately after calving and that thus intestinal absorption was the major inflow to the blood. This result is consistent with the finding of Mayer et al. (1969) that intravenous infusion of calcitonin was ineffective in lowering serum calcium during the puerperium. There are, however, several controlled experiments showing that bone resorption at the time around parturition is influenced by the type of feeding during the dry period (e.g. Block 1984). The primary aim of the present study was to compare the bone resorption rate immediately after calving in cows which had been tied indoors for $21 / 2$ years and in cows of the same age which had been given daily exercise during the same period of time.

\section{Material and methods}

The studies were performed in an experimental herd at the Department of Animal Nutrition and Management, Swedish University of Agricultural Sciences. The herd consisted of 48 cows of the Swedish Red and White Breed. 
When the studies were performed, half of the cows had been tied indoors for $21 / 2$ years, the other half had been given daily exercise during the same period. The herd consisted of 3rd and 4th calvers equally distributed between the 2 groups.

The exercised group was let out at 10.00 a.m. and forced to walk $1 \mathrm{~km}$ slowly, the cows were then allowed to return to the barn voluntarily and were taken inside at 2 p.m.. The indoor group had not access to feed during this period.

Both groups were fed indoors in the same way, at 6 a.m. and 2 p.m. The cows were fed hay, silage, concentrate, minerals and vitamins according to Swedish feeding standards and milked twice daily (6.45-7.45 a.m. and 2-2.45 p.m.).

Blood samples for analysis of calcium, inorganic phosphorus and magnesium were taken from the same 10 cows in each group. Sampling occurred 1-3 days before calving, the day of calving and then daily for the subsequent 5 days. The hypocalcemic response to protamine chlo- ride 1-3 days post partum was studied in 8 cows in the indoor group and in 5 cows in the exercised group. The dose of protamine chloride (10 $\mathrm{mg} / \mathrm{kg}$ body weight) was dissolved in $400 \mathrm{ml}$ of saline and given as a slow intravenous infusion (10 min.) Protamine chloride was obtained from Sigma Chemical Co. Blood was sampled at intervals shown in Fig. 1.

Blood for anlysis of vitamin D status was obtained in March, June, August and February. Ten cows in each group were sampled and serum was analysed for 25-(OH)-ergocalciferol $\left(\mathrm{D}_{2}\right)$ and 25- $(\mathrm{OH})$-cholecalciferol $\left(\mathrm{D}_{3}\right)$.

Blood minerals were analysed according to the routine methods of the Department of Clinical Chemistry. Vitamin D metabolites were analysed at the Experimental Station in Skara according to Holmberg et al. (1984). Student's t-test was used for statistical calculations.

\section{Results}

The serum mineral levels at the time around par-

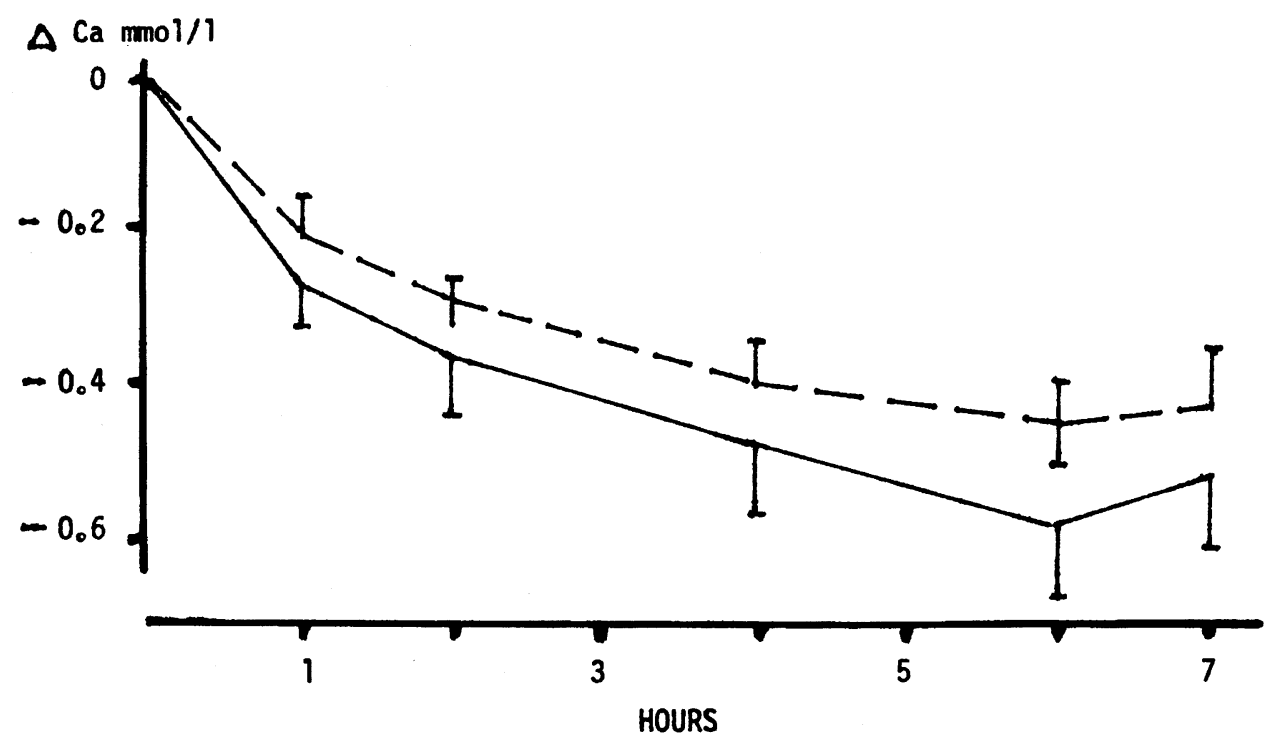

Figure 1. The hypocalcemic responce to intravenous injection of protamine chloride in exercised - - - - $(\mathrm{n}=5)$ and non-exercised - - - $(n=8)$ cows. $\mathrm{X} \pm$ SEM. 
Table 1. Mean serum mineral levels $(\overline{\mathrm{x}} \pm \mathrm{SEM})$ at the time around parturition in exercised and non-exercised dairy cows.

\begin{tabular}{|c|c|c|c|c|c|c|c|}
\hline & \multirow[t]{2}{*}{ Prepartus } & \multirow{2}{*}{$\begin{array}{l}\text { Day of } \\
\text { partus }\end{array}$} & \multicolumn{5}{|c|}{ Days post partus } \\
\hline & & & 1 & 2 & 3 & 4 & 5 \\
\hline $\begin{array}{l}\text { Non exercised } \\
(\mathrm{N}=10)^{* *}\end{array}$ & $2.43 \pm 0.07$ & $1.87 \pm 0.17$ & $2.30 \pm 0.10^{*}$ & $\begin{array}{l}\mathrm{Ca} \mathrm{mmol} / 1 \\
2.26 \pm 0.17\end{array}$ & $2.41 \pm 0.11$ & $2.37 \pm 0.11$ & $2.50 \pm 0.13$ \\
\hline $\begin{array}{l}\text { Exercised } \\
(\mathrm{N}=10\end{array}$ & $2.41 \pm 0.13$ & $1.98 \pm 0.23$ & $1.83 \pm 0.31$ & $\begin{array}{l}2.39 \pm 0.13 \\
\mathrm{P} \mathrm{mmol} / \mathrm{l}\end{array}$ & $2.55 \pm 0.10$ & $2.57 \pm 0.06$ & $2.61 \pm 0.09$ \\
\hline Non-exercised & $1.52 \pm 0.11$ & $1.13 \pm 0.26$ & $1.02 \pm 0.07$ & $1.55 \pm 0.16$ & $1.70 \pm 0.23$ & $1.71 \pm 0.23$ & $1.66 \pm 0.12$ \\
\hline Exercised & $1.68 \pm 0.11$ & $1.37 \pm 0.46$ & $1.30 \pm 0.20$ & $\begin{array}{c}1.28 \pm 0.16 \\
\mathrm{Mg} \mathrm{mmol} / 1\end{array}$ & $1.65 \pm 0.08$ & $1.76 \pm 0.10$ & $1.76 \pm 0.19$ \\
\hline Non exercised & $0.96 \pm 0.04$ & $1.12 \pm 0.06$ & $1.02 \pm 0.07$ & $1.08 \pm 0.16$ & $0.92 \pm 0.10$ & $0.76 \pm 0.03$ & $0.79 \pm 0.03$ \\
\hline Exercised & $0.98 \pm 0.04$ & $1.20 \pm 0.11$ & $1.11 \pm 0.11$ & $1.01 \pm 0.03$ & $0.87 \pm 0.02$ & $0.82 \pm 0.03$ & $0.86 \pm 0.05$ \\
\hline
\end{tabular}

$* 0.01<\mathrm{p}<0.05$

** One cow was excluded from day 2 because of clinical paresis.

turition are shown in Table 1. Clinical signs of parturient paresis occurred in 1 cow in the nonexercised group. The cow had to be treated the day after parturition and was excluded from further sampling. Low calcium levels $(1.05-1.46 \mathrm{mmol} / \mathrm{l})$ without clinical signs occurred in single cows in both groups. Serum calcium was normalized within 2-3 days in all animals. The mean calcium level was higher 1 day post partum $(\mathrm{p}<0.05, \mathrm{t}=2.997)$ in the non-exercised group, otherwise there were no significant differences between the groups.

The mean levels of inorganic phosphorus and magnesium did not differ. The lowest magnesium levels were found 4-5 days post partum. Single cows in both groups showed very low levels $(0.5 \mathrm{mmol} / \mathrm{l})$, however, clinical signs of hypomagnesemia did not occur during the observation period.

The changes in the serum levels of the vitamin D-metabolites are shown i Table 2. The level of 25-(OH)-ergocalciferol remained fairly constant during the year. An insignificant decline occurred in both groups. The means of 25-
(OH)-cholecalciferol was almost identical at the first sampling in March, in late summer (August) the exercised group showed a significantly higher level $(\mathrm{p}<0.001, \mathrm{t}=4.123)$. At the last sampling in February, the level had decreased in both groups and were significantly $(\mathrm{p}<0.001)$ lower than in March the preceeding year.

The hypocalcemic response to protamine is shown in Fig. 1. The preinjection level was $2.12 \pm 0.11 \mathrm{mmol} / \mathrm{l}$ in the non-exercised group. Two cows in this group showed levels $<2 \mathrm{mmol} / 1$ (1.73 and $1.63 \mathrm{mmol} / \mathrm{l})$. In the exercised group, the preinjection mean was $2.25 \pm 0.15 \mathrm{mmol} / /$. One cow in this group showed hypocalcæmia (1.57 $\mathrm{mmol} / \mathrm{l})$.

As shown in Fig. 1, serum calcium decreased in all cows after the injection. The decline was obvious already after $1 \mathrm{~h}$ and the lowest levels occurred after $6 \mathrm{~h}$.

The first injected cow developed clinical paresis after $8 \mathrm{~h}$, all the following cows were therefore given a therapeutic dose of calcium at the end of the sampling period. 
Table 2. Seasonal variations in the serum concentrations ( $\mathrm{ng} / \mathrm{ml}, \mathrm{x}+\mathrm{SEM})$ of vitamin $\mathrm{D}$ metabolites in exercised and non-exercised dairy cows.

\begin{tabular}{|c|c|c|c|c|}
\hline & March & June & August & February \\
\hline $\begin{array}{l}25(\mathrm{OH}) \mathrm{D}_{2}: \\
\text { Non-exercised } \\
(\mathrm{N}=10)\end{array}$ & $7.66 \pm 0.59$ & $7.74 \pm 1.02$ & $5.96 \pm 0.25$ & $5.82 \pm 0.50$ \\
\hline $\begin{array}{l}\text { Exercised } \\
(\mathrm{N}=10)\end{array}$ & $7.22 \pm 0.41$ & $5.33 \pm 0.96$ & $5.34 \pm 1.48$ & $4.41 \pm 0.20$ \\
\hline $\begin{array}{l}25(\mathrm{OH}) \mathrm{D}_{3}: \\
\text { Non-exercised } \\
\text { Exercised } \\
(\mathrm{N}=10)\end{array}$ & $\begin{array}{l}25.61 \pm 2.34 \\
25.13 \pm 1.81\end{array}$ & $\begin{array}{l}31.47 \pm 2.76 \\
38.53 \pm 3.09\end{array}$ & $\begin{array}{l}18.97 \pm 0.95 \\
32.43 \pm 3.13^{* * *}\end{array}$ & $\begin{array}{l}15.21 \pm 0.88 \\
13.64 \pm 0.98\end{array}$ \\
\hline
\end{tabular}

$* * * \mathrm{p}<0.001$

\section{Discussion}

The hypocalcemic effect of the heparin antagonist protamine was first described in man. Later studies showed that protamine inhibited bone resorption. A review of the older literature in this field was given by Luthman (1973a). The effect of protamine was studied in a series of experiments where the early results obtained in laboratory animals were verified in sheep and cattle (Luthman et al. 1973b, 1979, Persson \& Luthman 1975). As could be expected of a drug inhibiting bone resorption, the hypocalcemic effect was most obvious in physiological states where bone resorption is increased e.g. late pregnancy in sheep, early lactation in cattle and after treatment with pharmacological doses of vitamin $D_{3}$. It was concluded that injection of protamine was a simple indirect method for the study of the role of bone resorption in calcium homeostasis under different physiological conditions.

The earlier studies clearly showed that the hypocalcemic response to protamine was very moderate in post parturient cows, the response was significantly greater after 2 weeks. The protamine-induced hypocalcæmia illustrated in Fig. 1 is greater than earlier reported in post parturient cows (Luthman et al. 1977). The bone resorption rate, and thus also the response to protamine, may be influenced by several factors. It is e.g. well etablished that the ability to mobilize calcium from bone is reduced by age and that a prepartum diet high in calcium reduces the bone resorption rate after parturition (Allen \& Sansom 1985). The importance of the anion-cation balance of the prepartal diet was first pointed out by Dishington (1975) and it was later shown by Block (1984) that a prepartal diet containing an excess of anions increased the bone resorption rate after calving.

The earlier protamine studies were performed in hay-fed cows, in the present study the cows were fed silage and hay. It is, however, difficult to explain the unexpected response by means of the feeding records. The result indicates that regular exercise for a long period does not influence the bone resorption rate immediately post partum.

As shown in Table 1, there were no great differences in the serum calcium levels at the time around partus. Neither did inorganic phosphorus and magnesium differ.

The serum levels of 25-(OH)-ergocalciferol did not differ between the groups. The levels remained fairly constant during the observation period. The mean of $25-(\mathrm{OH})$-cholecalciferol was significantly higher in the exercised group in August, otherwise there were no differences. 
Sturén (1986) reported similar levels of 25$(\mathrm{OH})$-ergocalciferol as in the present study in cows fed hay and silage. The higher level of 25$(\mathrm{OH})$-cholecalciferol in the exercised group obviously reflects the exposure to sunlight. Sturén reported higher levels in cows on pasture ( $>40 \mathrm{ng} / \mathrm{ml})$. Cows on pasture are, however, exposed to sunlight for a longer daily period than the cows in the exercised group which were kept outdoors for only $4 \mathrm{~h}$ daily.

The cows were fed a vitamin D containing additive and the intake was considered to be the same over the year. It is, however, obvious that the intake varied, since the serum levels were significantly higher when the study was initiated than in February the following year.

The aim of the present study was to investigate how regular exercise influences the bone resorption rate. The results from the protamine injections indicate that bone resorption did not differ between exercised and non-exercised cows. However, outdoor exercise increased the serum level of 25-(OH)-cholecalciferol significantly.

\section{References}

Allen WM, Sansom BF: Milk fever and calcium metabolism. J.vet. Pharmacol.Therap. 1985, 8, 19-29.

Block E: Manipulating dietary anions and cations for prepartum dairy cows to reduce incidence of milk fever. J.Dairy Sci. 1984, 67, 2939-2948.

Braithwaite GD: Reviews of the progress of dairy science. Calcium and phosphorus metabolism in ruminants with special reference to parturient paresis. J. Dairy Sci. 1976, 43, 501-520.

Holmberg I, Kristiansen T, Sturén M: Determination of 25-hydroxi-vitamin D in serum by high performance liquid chromatography and isotope dilution - mass spectrometry. Scand.J.clin.Lab.Invest. 1984, 44, 275-282.

Luthman J, Jonsson G, Persson J: The hypocalcaemic effect of protamine in goats and sheep. Zbl.Vet.Med. A, 1973a, 20, 110-115.

Luthman J, Jonsson G, Persson J: The hypocalcaemic response to protamine as a measure of bone resorption. Acta vet.scand. 1973b, 14, 428-435.

Luthman J, Jacobsson SO, Nilsson G: The effect of concentrate feeding on calcium metabolism och plasma gastrin concentration in parturient cows. Acta vet.scand. 1979, 20, 546-554.

Mayer GP, Ramberg CF, Kronfeld DS: Calcium homeostasis in the cow. Clin.Orthop. 1969, 62, 79-94.

Persson J, Luthman J: Factors affecting the hypocalcaemic response to protamine. Acta vet.scand. 1975, 16, 1-12.

Ramberg CF, Mayer GP, Kronfeld DS, Phang JM, Bergman M: Calcium kinetics in cows during late pregnancy parturition, and early lactation. Amer.J.Physiol. 1970, 219, 1166-1177.

Sturén M: Variations in serum $25-\mathrm{OH}-\mathrm{D}_{2}$ and $25-$ $\mathrm{OH}-\mathrm{D}_{3}$ concentrations in Swedish dairy cattle under different management conditions. Proc. XIVth Congress on Diseases in Cattle, Dublin 1986, 763-768.

\section{Sammanfattning}

Vitamin D status och det hypokalcemiska svaret på protamin hos motionerade och icke motionerade mjölkkor.

Protamin blockerar benresorbtionen. Protamininducerad hypokalcemi kan därför användas som ett mått på benresorbtionens roll i kalcium-homeostasen. Studierna utfördes i en besättning där hälften av korna hållits kontinuerligt uppbundna inomhus under $21 / 2$ år, övriga djur hade givits daglig motion utomhus under samma period. Samtliga kor utfodrades på samma sätt.

Det hypokalcemiska svaret efter protamininjektion var av samma storlek i båda grupperna, vilket indikerar att motion ej påverkar benresorb-tionen post partum. Vid tiden kring partus förelåg inga skillnader i serumkoncentrationerna av kalcium, oorganisk fosfor och magnesium mellan de båda grupperna. Under sensommaren var serumkoncentrationen av 25-(OH)-cholecalciferol signifikant högre i den motionerade gruppen.

(Received November 3, 1992; accepted November 18, 1992).

Reprints may be requested from: J. Luthman, Department of Cattle and Sheep Diseases, Swedish University of Agricultural Sciences, Box 7019, S-750 07 Uppsala, Sweden. 
